\title{
Phase Diagram of the Sn-As-Ge System
}

\author{
Galina V. Semenova, Elena Yu. Proskurina, Tatiana P. Sushkova* \\ and Victor N. Semenov \\ Department of General and Inorganic Chemistry, Voronezh State University; Universitetskaya pl., 1, \\ Voronezh, 394018, Russia \\ * Corresponding author: E-mail: sushtp@yandex.ru
}

Received: 11-03-2018

\begin{abstract}
The paper presents the phase diagram of the Sn-As-Ge system. The diagram of polythermal Sn-GeAs section was constructed using the results of $\mathrm{X}$-ray powder diffraction analysis and differential thermal analysis. We found that in a concentration interval with arsenic content of less than $50 \mathrm{~mol} \%$, four-phase peritectic equilibria $\mathrm{L}+\mathrm{SnAs} \leftrightarrow \mathrm{GeAs}+\mathrm{Sn}_{4} \mathrm{As}_{3}$ $(834 \mathrm{~K})$ and $\mathrm{L}+\mathrm{GeAs} \leftrightarrow \mathrm{Ge}+\mathrm{Sn}_{4} \mathrm{As}_{3}(821 \mathrm{~K})$ are present. When the temperature is close to the melting point of pure tin, non-variant equilibrium with tin, germanium and $\mathrm{Sn}_{4} \mathrm{As}_{3}$ is implemented as well. The study of $\mathrm{Sn}_{0.39} \mathrm{As}_{0.61}-\mathrm{Ge}_{0.28} \mathrm{As}_{0.72}$, $\mathrm{SnAs}-\mathrm{Ge}_{0.4} \mathrm{As}_{0.6}$ and $\mathrm{SnAs}-\mathrm{GeAs}_{2}$ sections and elaboration of the type of the $\mathrm{SnAs}-\mathrm{GeAs}$ phase diagram demonstrated that polythermal sections $\mathrm{SnAs}-\mathrm{GeAs}$ and $\mathrm{SnAs}-\mathrm{GeAs}_{2}$ can perform phase subsolidus demarcation of the phase diagram of the Sn-As-Ge system. There are also invariant peritectic equilibria L + GeAs $\leftrightarrow$ GeAs + SnAs (840 K) and L + As $\leftrightarrow$ $\mathrm{SnAs}+\mathrm{GeAs}_{2}(843 \mathrm{~K})$ in the system.
\end{abstract}

Keywords: Phase diagram; germanium arsenide; tin arsenide; ternary system

\section{Introduction}

A large number of experimental and theoretical studies of the properties of graphene have provoked considerable scientific interest in layered structures, and compounds of the $\mathrm{A}^{\mathrm{IV}} \mathrm{B}^{\mathrm{V}}$ class in particular. $\mathrm{A}^{\mathrm{IV}} \mathrm{B}^{\mathrm{V}}$ compounds are of great practical value for two reasons: their anisotropic electrophysical characteristics resulting from low-symmetry structure; and their layered crystal structure which allows for the intercalation of ions and molecules into the interlayer space. ${ }^{1-5}$ The presence of volatiles makes it rather difficult to synthesise such compounds, which is why attempts were made to obtain GeP samples in the presence of tin. ${ }^{5}$ In that study, Sn-doped materials with peculiar semiconductor properties were obtained. However, the lack of information about the phase equilibria of $\mathrm{A}^{\mathrm{IV}}-\mathrm{B}^{\mathrm{V}}-\mathrm{Sn}$ ternary systems makes further research in this area rather problematic. Therefore, since the synthesis of multicomponent alloys is based on information about phase equilibria, the study of the phase diagram of the $\mathrm{Sn}-\mathrm{As}-\mathrm{Ge}$ system is of great importance.

This paper presents the results of an experimental study of $\mathrm{Sn}-\mathrm{GeAs}, \mathrm{Sn}_{0.39} \mathrm{As}_{0.61}-\mathrm{Ge}_{0.28} \mathrm{As}_{0.72}, \mathrm{SnAs}-\mathrm{Ge}_{0.4} \mathrm{As}_{0.6}$,
SnAs-GeAs and SnAs-GeAs, polythermal sections, which was performed using differential thermal analysis and $\mathrm{X}$-ray phase analysis methods. T- $x$ diagrams of the sections were constructed, and the nature of phase equilibria in the ternary $\mathrm{Sn}-\mathrm{As}-\mathrm{Ge}$ system was analysed.

\section{Experimental}

\section{1. Materials and Synthesis}

The number of ternary alloys with compositions corresponding to $\mathrm{Sn}-\mathrm{GeAs}, \mathrm{Sn}_{0.39} \mathrm{As}_{0.61}-\mathrm{Ge}_{0.28} \mathrm{As}_{0.72}$, SnAs$\mathrm{Ge}_{0.4} \mathrm{As}_{0.6}$, SnAs-GeAs and SnAs-GeAs ${ }_{2}$ polythermal sections, were prepared from the preliminary obtained binary compounds using high purity tin Sn-5N (99.999\%), arsenic As-5N (99.9997\%) and polycrystalline zone purified germanium Ge-5N-6N (99.9999\%). Weighing was performed on an AR2140 balance with an accuracy of \pm 0.001 g. The preparation of samples was carried out using the one-temperature method in thick-walled quartz ampoules vacuumised up to the residual pressure of $0.05 \mathrm{~Pa}$. During the synthesis of the samples, the temperature was measured using a chromel-alumel thermocouple with a TK- 
5.11 contact thermometer. The alloys were subjected to homogenizing annealing for 150 hours at $800-815 \mathrm{~K}$.

\section{2. Research Methods}

The study of the samples obtained was carried out on the differential thermal analysis (DTA) setup with a programmable heating of the furnace using OWEN TRM-151 and TRM-202 proportional-integral-differential controllers. The signal received from chromel-alumel thermocouples was digitized and processed by the MasterSCADA software package. In our experiments, the heating rate of DTA-setup was $5 \mathrm{~K} \mathrm{~min}^{-1}$.

Thermoanalytical studies were carried out using Stepanov's quartz vessels. The experimental substance was ground and placed in the vessels so as to fill the maximum volume, after which the vessels were vacuumised up to the residual pressure of $0.05 \mathrm{~Pa}$. Anhydrous analytically pure aluminum oxide was used as the reference substance. Chromel-alumel thermocouples, used as temperature sensors, were calibrated according to the phase transitions temperatures of pure metals, often used as standards. ${ }^{6}$ Furthermore, Sn, As and $\mathrm{Ge}$ were used. Their physical and chemical properties are similar to the properties of the objects we were studying. The precision of determining the temperature of phase transition by the DTA-setup was within the limit of $\pm 2 \mathrm{~K}$.

$\mathrm{X}$-ray powder diffraction (XRD) analysis of alloy samples of the sections $\mathrm{Sn}-\mathrm{GeAs}$, SnAs- $\mathrm{Ge}_{0,4} \mathrm{As}_{0,6}$, SnAsGeAs were performed using a powder difractometer ARLX'TRA with the following characteristics: CuKa-radiation, exposure step $0.06^{\circ}$, exposure time 3.0 seconds. The samples of the sections $\mathrm{Sn}_{0.39} \mathrm{As}_{0.61}-\mathrm{Ge}_{0.28} \mathrm{As}_{0.72}$ и $\mathrm{SnAs}-$ $\mathrm{GeAs}_{2}$ were performed using a powder difractometer DRON 4-07 (CoKa-radiation, exposure step 0.1 ${ }^{\circ}$, exposure time 3.0 seconds). The intermediate phases in the $\mathrm{Ge}-$ Sn-As system have the following crystal structure: SnAs Cubic, space group Fm3m; $\mathrm{Sn}_{4} \mathrm{As}_{3}$ - Rhombohedral, space group R3m; GeAs - Tetragonal, space group 14mm; GeAs - Orthorhombic, space group Pbam. The recorded X-ray powder diffraction patterns were interpreted using the Powder Diffraction File cards of International Centre for Diffraction Data (ICDD PDF-2 2007).

\section{Results and Discussion}

In our previous experimental study of polythermal sections $\mathrm{Sn}_{4} \mathrm{As}_{3}-\mathrm{GeAs}$ and $\mathrm{SnAs}-\mathrm{GeAs}^{7}$ it was showed that a peritectic equilibrium $\mathrm{L}+\mathrm{SnAs} \leftrightarrow \mathrm{Sn}_{4} \mathrm{As}_{3}+\mathrm{GeAs}$ was achieved in the $\mathrm{Ge}-\mathrm{As}-\mathrm{Sn}$ system at the temperature of $834 \mathrm{~K}$. This conclusion we confirmed by the study of the alloys of the polythermal section $\mathrm{Ge}-\mathrm{SnAs},{ }^{8}$ that was based on the results of an X-ray diffraction analysis and differential thermal analysis. The existence of yet another invariant equilibrium $\mathrm{L}+\mathrm{GeAs} \leftrightarrow \mathrm{Ge}+\mathrm{Sn}_{4} \mathrm{As}_{3}$, which is realized at a temperature of $821 \mathrm{~K}$, was also established. ${ }^{8}$
In this paper, the alloys belonging to the $\mathrm{Sn}-\mathrm{GeAs}$ section were studied. An X-ray diffraction analysis showed that for all the samples in the solid state, the presence of three phases is detected: irrespective of the composition, the lines of germanium and tin arsenide $\mathrm{Sn}_{4} \mathrm{As}_{3}$ are fixed. Depending on the third phase contained in the alloys, the samples can be divided into two groups. When the content of germanium arsenide is up to $60 \mathrm{~mol} . \%$, the alloys are a heterophasic mixture of tin and germanium, as well as $\mathrm{Sn}_{4} \mathrm{As}_{3}$ (e.g., the X-ray diffraction pattern in Fig. 1a). For the alloys with germanium arsenide content of 67-94 mol.\%, there are no reflexes characteristic of tin; on the contrary, lines indicating the presence of germanium monoarsenide in the solid phase appear, and the intensity of these lines increases with the enrichment of the alloys with this component (Fig. 1b).

The investigation of the alloys by differential thermal

a)

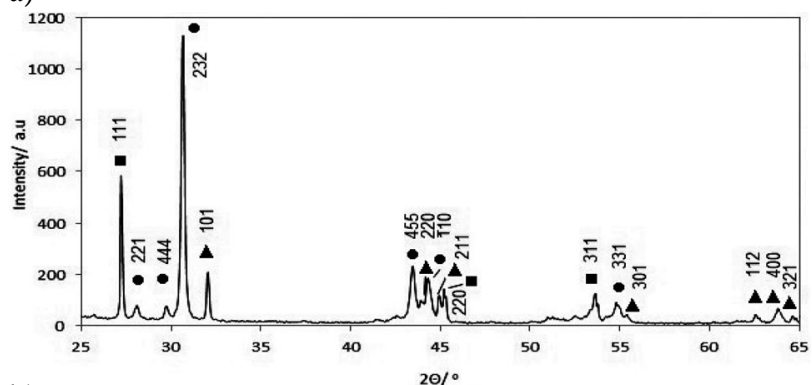

b)

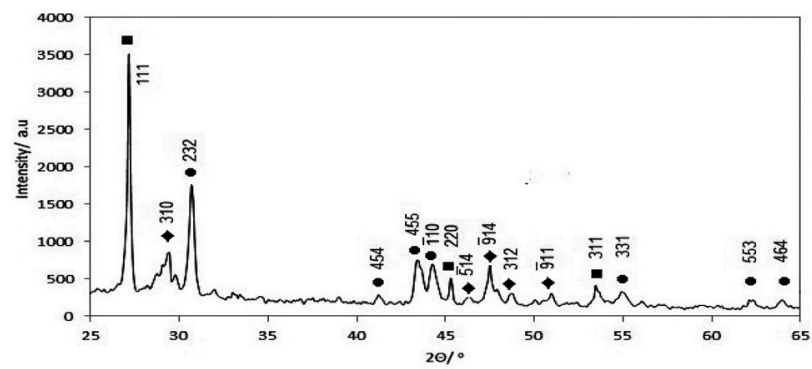

Figure 1. XRD patterns of the alloys of the polythermal section $\mathrm{Sn}-$ GeAs: $\mathrm{a}-0.33$; b -0.82 mol. f. GeAs. The symbols denote: $\bullet$ $\mathrm{Sn}_{4} \mathrm{As}_{3} ; \mathbf{- G e} ; \boldsymbol{\Delta}-\mathrm{Sn} ;-\mathrm{GeAs}$.

analysis showed that when the content of germanium arsenide is more than $60 \mathrm{~mol}$. \% three endothermic effects were fixed, and the low-temperature effect was observed at the same temperature of $821 \mathrm{~K}$. According to our data obtained from the study of the polythermal cross section of $\mathrm{Ge}-\mathrm{SnAs},{ }^{8}$ this corresponds to the four-phase process $\mathrm{L}+$ $\mathrm{GeAs} \leftrightarrow \mathrm{Ge}+\mathrm{Sn}_{4} \mathrm{As}_{3}$. The second effect at $939 \mathrm{~K}$ was noted for the samples in the range of 82-94 mol.\% GeAs compositions. The high-temperature effect corresponding to the liquidus on the heating curves was not very distinct, but was well reproduced on the cooling curves. For samples with a monoarsenide germanium content of less than $60 \mathrm{~mol} . \%$, the effect at $821 \mathrm{~K}$ was absent, for all the alloys 
of a given concentration interval, an endothermic effect is realized at $505 \mathrm{~K}$.

Fig. 2 shows phase equilibria in the $\mathrm{Sn}-\mathrm{As}-\mathrm{Ge}$ system within the concentration interval of less than 50 mol.\% As. This allows for correct interpretation of the experimental results of studying the T-x diagram of the SnGeAs section.

The presence of a horizontal section on the T-x cut chart (the first effect on heating curves) corresponds to a invariant four-phase equilibrium in the ternary system. According to an X-ray diffraction analysis in the composition range of less than $60 \mathrm{~mol} \% \mathrm{GeAs}$, there are three solid phases: tin, germanium and $\mathrm{Sn}_{4} \mathrm{As}_{3}$. Thus, we can assume the existence of a four-phase equilibrium $\mathrm{L} \leftrightarrow \mathrm{Sn}_{4} \mathrm{As} s_{3}+\mathrm{Ge}$ $+\mathrm{Sn}$ in the system, which is realized at a temperature of $505 \mathrm{~K}$. Tin is absent in the region of compositions rich in GeAs, but three solid phases are still recorded: Ge, $\mathrm{Sn}_{4} \mathrm{As}_{3}$ and GeAs.

The alloys the compositions of which correspond to the concentration region $a b$ (Fig. 2) of the polythermal section lie in the region of primary crystallization of the germanium monoarsenide $\mathrm{L} \leftrightarrow$ GeAs. Secondary crystallization is connected with the three-phase equilibrium line $\mathrm{e}_{3} \mathrm{U}_{4}$, along which the process $\mathrm{L} \leftrightarrow \mathrm{GeAs}+\mathrm{Ge}$ is carried out. The crystallization ends at $\mathrm{U}_{4}$ point: $\mathrm{L}+\mathrm{GeAs} \leftrightarrow \mathrm{Ge}+$ $\mathrm{Sn}_{4} \mathrm{As}_{3}$. The segment $c d$ intersects the field of primary crystallization of germanium. After the primary crystallization, the figurative point of the liquid falls on the curve $\mathrm{U}_{4} \mathrm{E}_{1}$. The process ends with eutectic crystallization at the point $\mathrm{E}_{1}$ (the temperature of this four-phase transformation noted by the DTA method is $505 \mathrm{~K}$ ). The sequence of processes will be as follows: $\mathrm{L} \leftrightarrow \mathrm{Ge} ; \mathrm{L} \leftrightarrow \mathrm{Ge}+\mathrm{Sn}_{4} \mathrm{As}_{3}$; $\mathrm{L}$ $\leftrightarrow \mathrm{Ge}+\mathrm{Sn}_{4} \mathrm{As}_{3}+\mathrm{Sn}$. The segment $c d$ also crosses the field of primary crystallization of tin. However, taking into account the degenerate nature of the eutectic processes $e_{1} E_{1}$ and $e_{2} E_{1}$, it should be assumed that the four-phase and preceding three-phase processes will occur in a narrow concentration interval (p. $\mathrm{E}_{1}-$ is degenerated) and it is not possible to investigate them. The presented reasoning makes it possible to interpret the data of differential thermal analysis and construct the T-x diagram of the polythermal section of Sn-GeAs (Fig. 3).

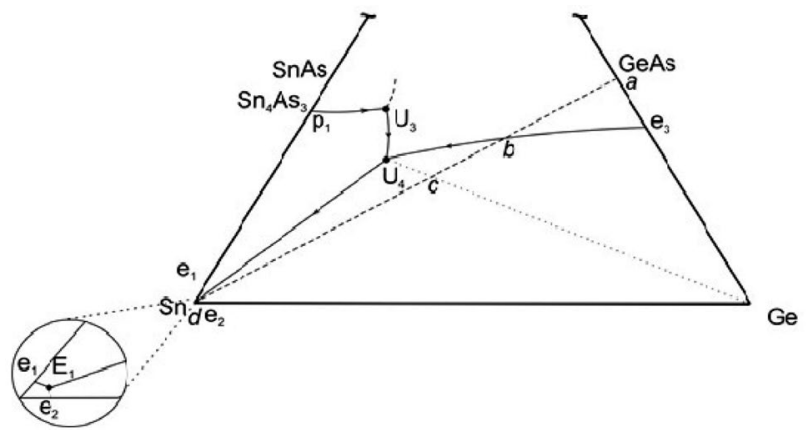

Figure 2. Crystallization processes of the alloys of the polythermal section $\mathrm{Sn}-\mathrm{GeAs}$.
While studing the SnAs-GeAs polythermal section ${ }^{7}$ it was suggested that this section is quasibinary and can be presented as a eutectic phase diagram with coordinates of the eutectic point $840 \mathrm{~K}$ and $20 \mathrm{~mol} \% \mathrm{GeAs}$. The results of the experimental study of the polythermal section SnAs$\mathrm{Ge}_{0.4} \mathrm{As}_{0.6}$ allowed us to elaborate the $\mathrm{T}-\mathrm{x}$ diagram of SnAs-GeAs. The polythermal section SnAs- $\mathrm{Ge}_{0.4} \mathrm{As}_{0.6}$ starts from the figurative point of tin monoarsenide and from the double eutectic point $\left(\mathrm{GeAs}_{2}+\mathrm{GeAs}\right)$ in the

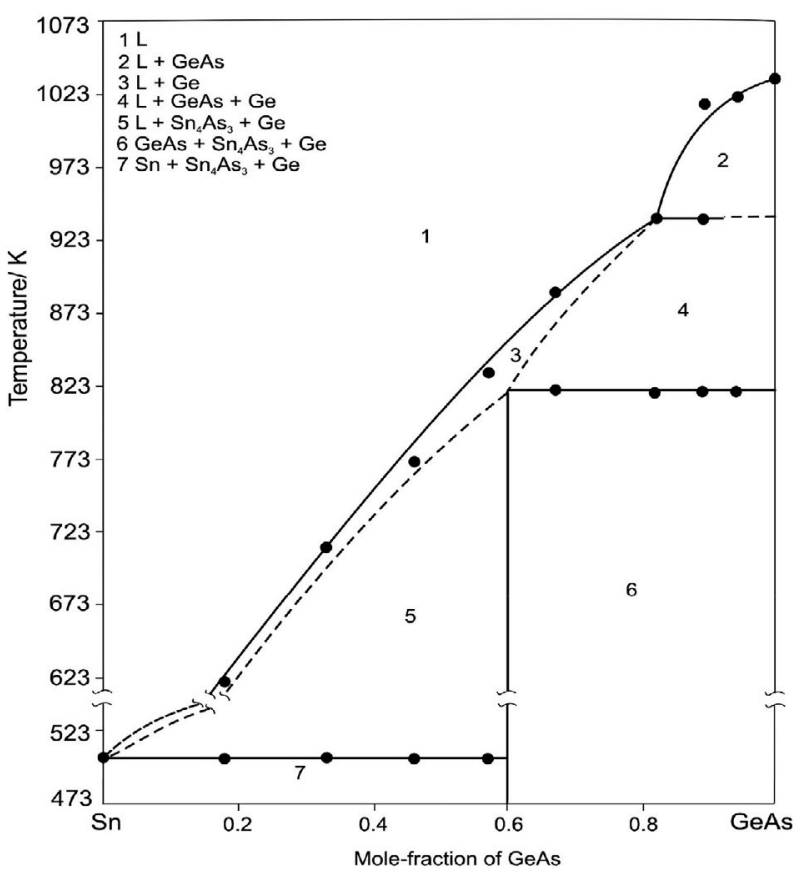

Figure 3. $T-x$ diagram of the polythermal section $\mathrm{Sn}-\mathrm{GeAs}$.

a)

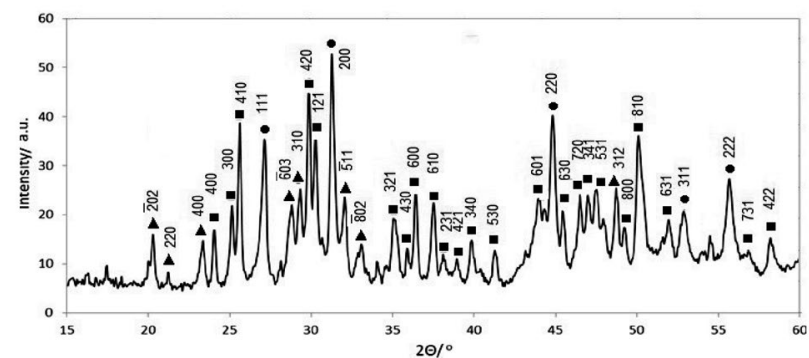

b)

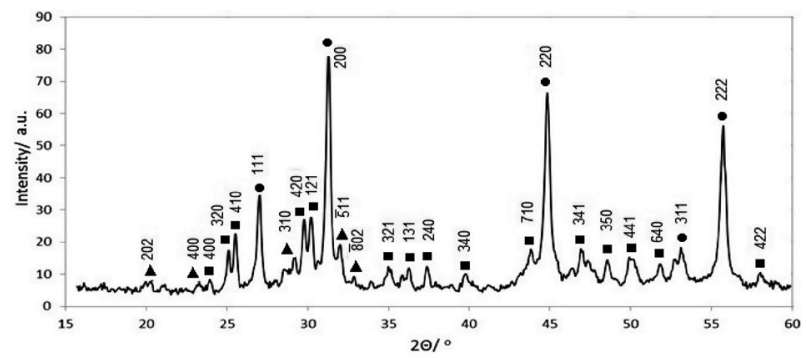

Figure 4. XRD patterns of the alloys of the polythermal section SnAs- $\mathrm{Ge}_{0.4} \mathrm{As}_{0.6} \mathrm{a}-\mathrm{a}$ - $15 ; \mathrm{b}-0.75$ mol.f. SnAs. The symbols denote: - - SnAs; $\boldsymbol{\square}-\mathrm{GeAs}_{2} ; \boldsymbol{\Delta}$ - GeAs. 
$\mathrm{Ge}-\mathrm{As}$ system. The alloys of the polythermal section SnAs- $\mathrm{Ge}_{0.4} \mathrm{As}_{0.6}$ are the mixtures of GeAs, $\mathrm{GeAs}_{2}$ and SnAs. XRD patterns of some of the alloys are given as an example in Fig. 4 a, b.

The results of the differential thermal analysis showed that the first endothermic effect for all the samples of the SnAs- $\mathrm{Ge}_{0.4} \mathrm{As}_{0.6}$ section was observed at the temperature of 840 K. In Fig. 5 as an example, thermograms of alloys of two sections are presented: SnAs-GeAs and $\mathrm{SnAs}-\mathrm{Ge}_{0.4} \mathrm{As}_{0.6}$. For the alloys of the section SnAs-GeAs (Fig. 5a), two endothermic effects are observed, and for the cut $\mathrm{SnAs}-\mathrm{Ge}_{0.4} \mathrm{As}_{0.6}$, there are three effects, which can be clearly seen on the cooling curves. The beginning of the first endothermic effect is the same for both samples -840 K. For greater clarity, on Fig. 6 the thermograms in the coordinates $\Delta \mathrm{T}$ - $\mathrm{T}$ are compared.

a)

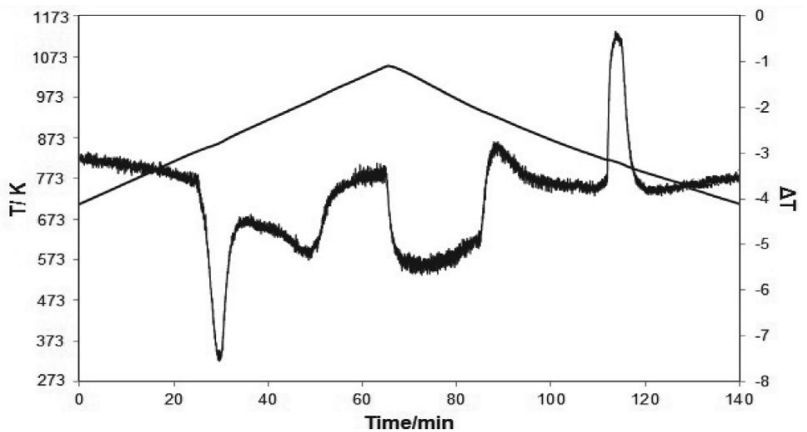

b)

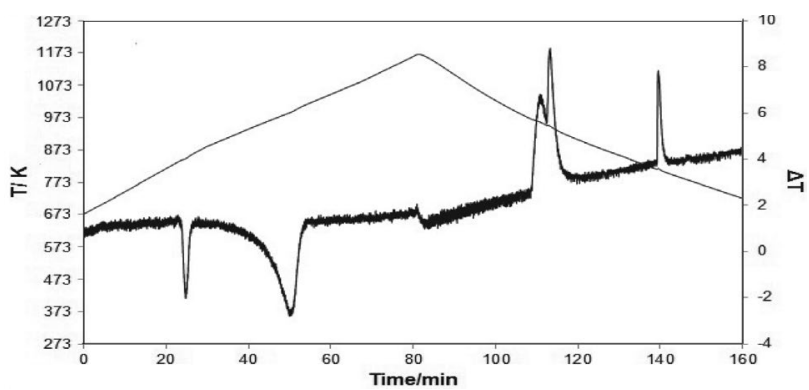

Figure 5. Thermograms for $(\mathrm{SnAs})_{0.4}(\mathrm{GeAs})_{0.6}(\mathrm{a})$ and $(\mathrm{SnAs})_{0.15}$ $\left(\mathrm{Ge}_{0.4} \mathrm{As}_{0.6}\right)_{0.85}$ (b) alloys

a)

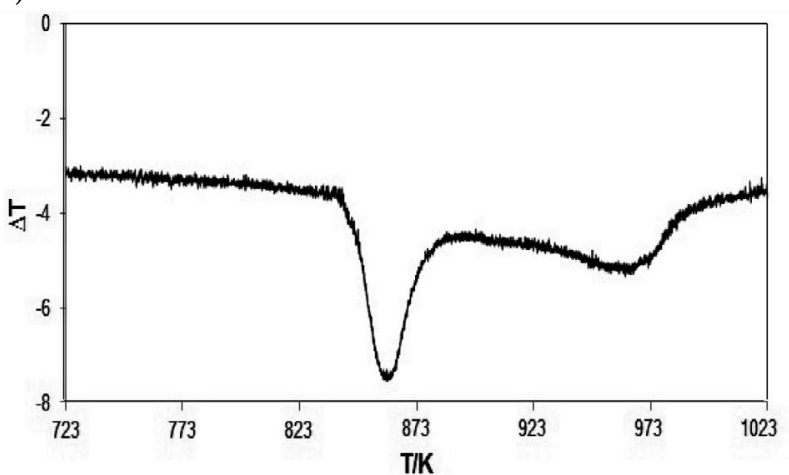

If there is an eutectic equilibrium with three solid phases $\mathrm{SnAs}+\mathrm{GeAs}+\mathrm{GeAs}_{2}$, a lower temperature corresponding to the melting of the triple eutectic should be expected. The results obtained can be explained, if we assume that the ternary $\mathrm{Sn}-\mathrm{As}-\mathrm{Ge}$ system includes a peritectic four-phase equilibrium $\mathrm{L}+\mathrm{GeAs}_{2} \leftrightarrow \mathrm{GeAs}+\mathrm{SnAs}$. Taking this into account, a $T-x$ diagram of the polythermal section $\mathrm{SnAs}-\mathrm{Ge}_{0.4} \mathrm{As}_{0.6}$ was constructed, and the form of the polythermal section SnAs-GeAs was specified (Fig. 7 a, b).

a)

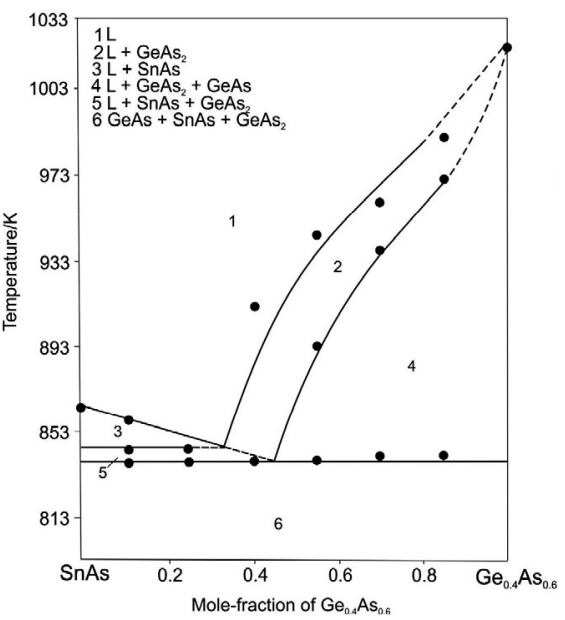

b)

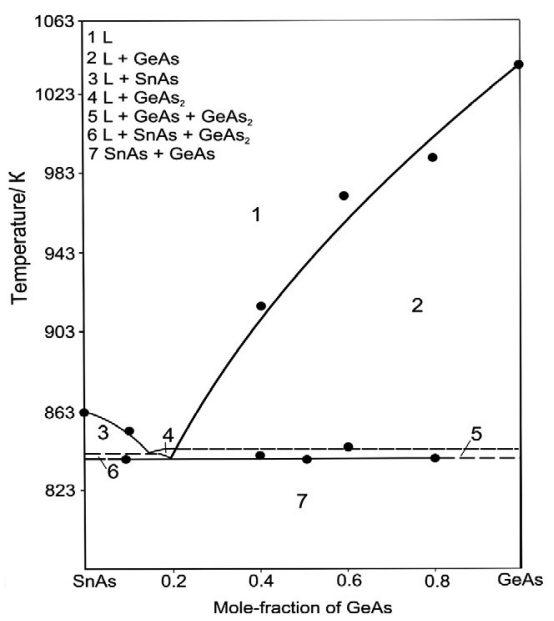

Figure 7. T-x diagrams of polythermal sections $\mathrm{SnAs}-\mathrm{Ge}_{0.4} \mathrm{As}_{0.6}$ (a) and SnAs-GeAs (b).

b)

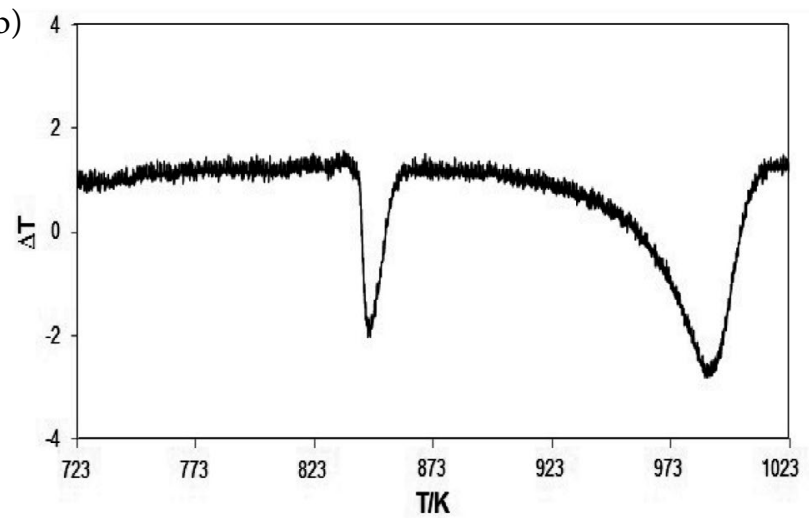

Figure 6. The DTA results in $\Delta \mathrm{T}-\mathrm{T}$ coordinates for $(\mathrm{SnAs})_{0.4}(\mathrm{GeAs})_{0.6}(\mathrm{a})$ and $(\mathrm{SnAs})_{0.15}\left(\mathrm{Ge}_{0.4} \mathrm{As}_{0.6}\right)_{0.85}$ (b) alloys 
In order to establish the nature of phase equilibria in the $\mathrm{Sn}-\mathrm{As}-\mathrm{Ge}$ system within the concentration interval of more than $50 \mathrm{~mol} \%$ of arsenic, an experimental study of the polythermal sections $\mathrm{Sn}_{0.39} \mathrm{As}_{0.61}-\mathrm{Ge}_{0.28} \mathrm{As}_{0.72}$ and $\mathrm{SnAs}-\mathrm{GeAs}_{2}$ was carried out. The X-ray diffraction analysis of the alloys belonging to the polythermal section $\mathrm{SnAs}-\mathrm{GeAs}_{2}$ allowed us to detect a heterophasic mixture of two phases - tin monoarsenide and germanium diarsenide (Fig. 8 a, b).

a)

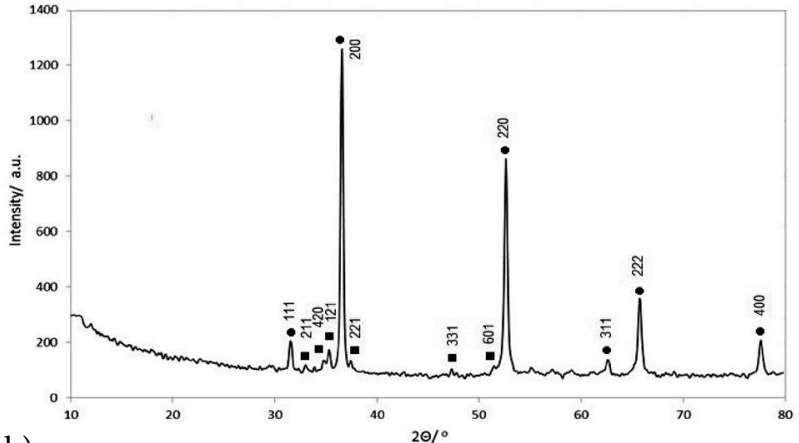

b)

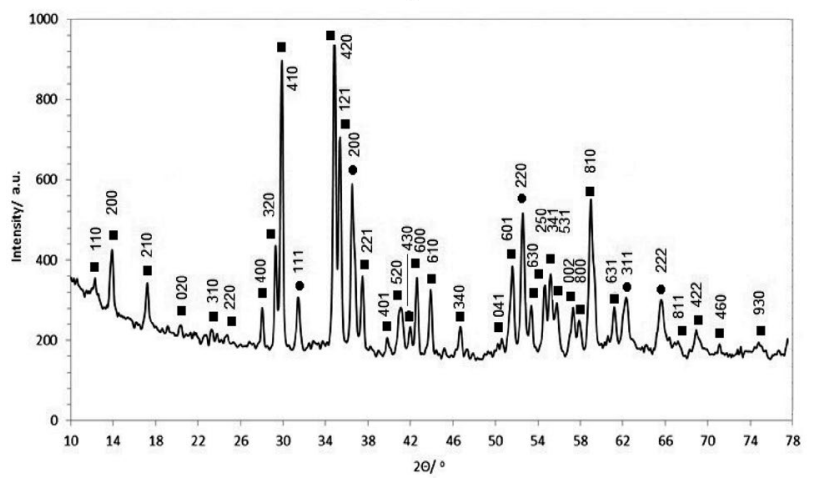

Figure 8. XRD patterns of the alloys of the polythermal section SnAs-GeAs 2 : a - 0.25; b - 0.85 mol.f. GeAs 2 . The symbols denote: $\bullet$ - SnAs; - - $\mathrm{GeAs}_{2}$.

Using differential thermal analysis allowed us to detect the endothermic effect in the samples of all concentration range at the same temperature of $843 \mathrm{~K}$. The polythermal section $\mathrm{Sn}_{0.39} \mathrm{As}_{0.61}-\mathrm{Ge}_{0.28} \mathrm{As}_{0.72}$ goes through the a)

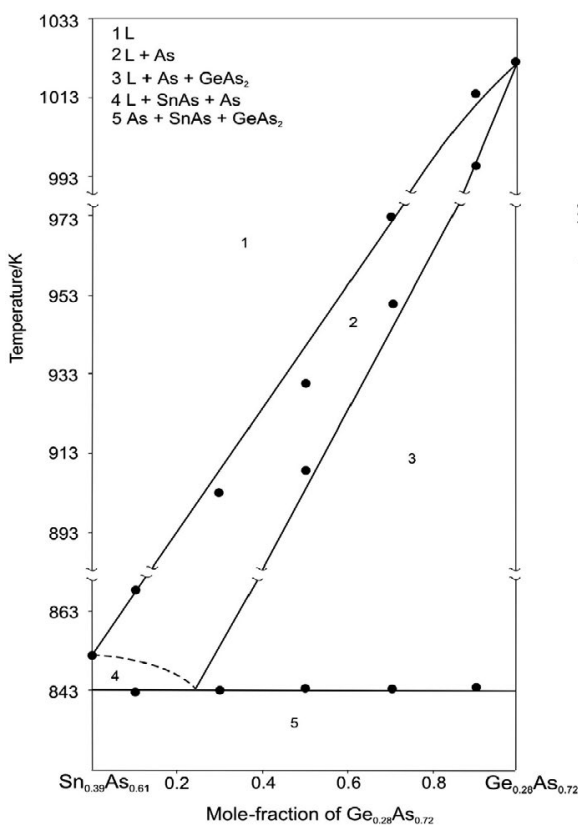

b)

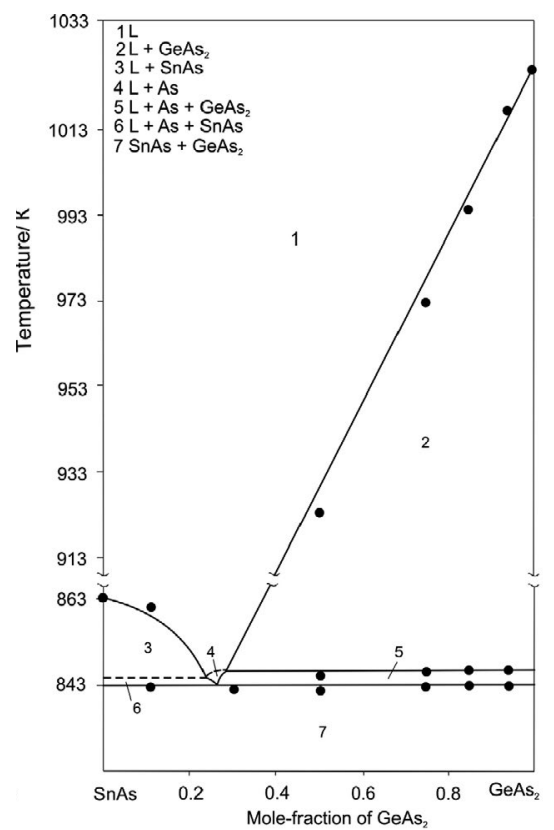

Figure 10. T-x diagrams of polythermal sections $\mathrm{Sn}_{0.39} \mathrm{As}_{0.61-}$ $\mathrm{Ge}_{0.28} \mathrm{As}_{0.72}$ (a) and SnAs-GeAs $(\mathrm{b})$. a)

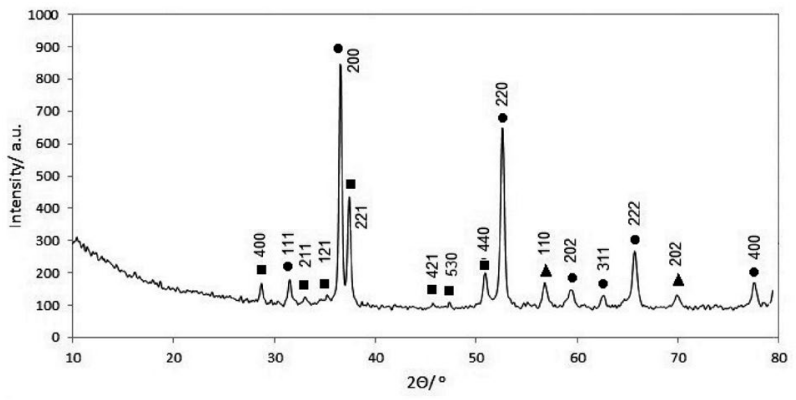

b)

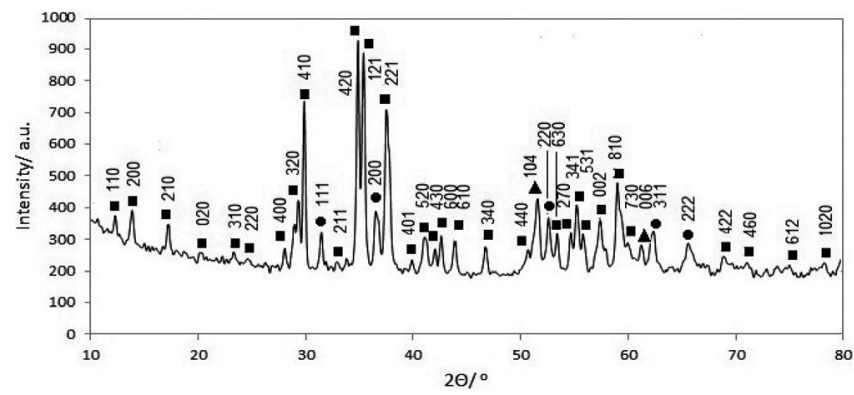

Figure 9. XRD patterns of the alloys of the polythermal section $\mathrm{Sn}_{0.39} \mathrm{As}_{0.61}-\mathrm{Ge}_{0.28} \mathrm{As}_{0.72}: \mathrm{a}-0.10 ; \mathrm{b}-0.90 \mathrm{~mol}^{\mathrm{f} .} \mathrm{Ge}_{0.28} \mathrm{As}_{0.72}$. The symbols denote: - SnAs; - $-\mathrm{GeAs}_{2} ; \boldsymbol{\Delta}$ - As. 
double eutectic point $\left(\mathrm{GeAs}_{2}+\mathrm{As}\right)$ in the binary system Ge-As and through the eutectic point (SnAs + As) in the $\mathrm{Sn}$-As system. The alloys whose compositions belong to the polythermal section $\mathrm{Sn}_{0.39} \mathrm{As}_{0.61}-\mathrm{Ge}_{0.28} \mathrm{As}_{0.72}$ represent a heterophasic mixture of arsenic, germanium diarsenide and tin monoarsenide (Fig. 9 a, b).

Phase diagram of the $\mathrm{Sn}_{0.39} \mathrm{As}_{0.61}-\mathrm{Ge}_{0.28} \mathrm{As}_{0.72}$ section is shown in Fig. 10a. Differential thermal analysis demonstrated that in all the samples the first endothermic effect was observed at the same temperature of $843 \mathrm{~K}$ (Fig. $11,12)$. Implementation of the same temperature at the section SnAs-GeAs ${ }_{2}$ (Fig. 10b) allows us to conclude that there exists a peritectic invariant equilibrium $\mathrm{L}+\mathrm{As} \leftrightarrow$ $\mathrm{SnAs}+\mathrm{GeAs}_{2}$.

a)

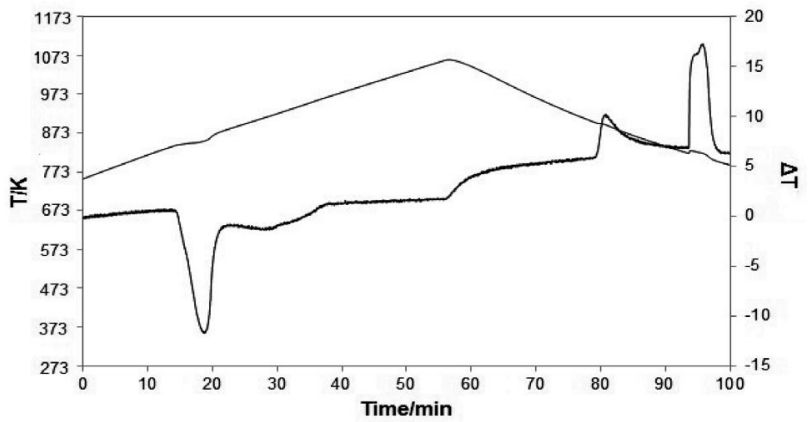

b)

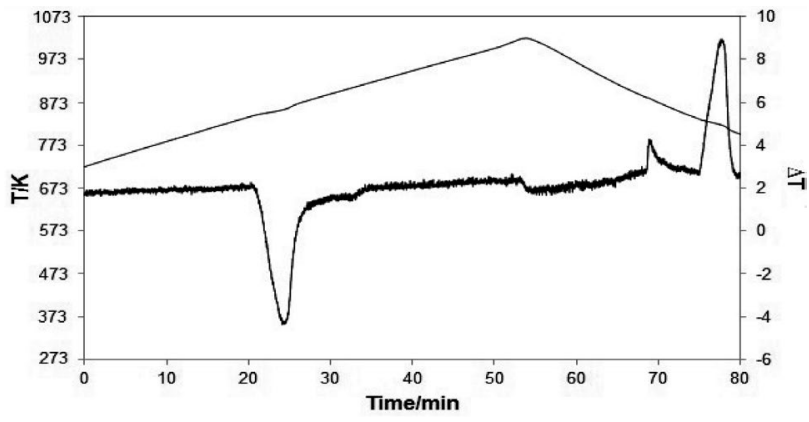

Figure 11. Thermograms for $(\mathrm{SnAs})_{0.5}\left(\mathrm{GeAs}_{2}\right)_{0.5}$ (a) and $\left(\mathrm{Sn}_{0.39}\right.$ $\left.\mathrm{As}_{0.61}\right)_{0.7}\left(\mathrm{Ge}_{0.28} \mathrm{As}_{0.72}\right)_{0.3}$ (b) alloys.

Thus, there are four equilibria of peritectic character in the ternary system of $\mathrm{Sn}-\mathrm{As}-\mathrm{Ge}$ :

1. $\mathrm{L}+\mathrm{As} \leftrightarrow \mathrm{SnAs}+\mathrm{GeAs}_{2}$

2. $\mathrm{L}+\mathrm{GeAs}_{2} \leftrightarrow \mathrm{GeAs}+\mathrm{SnAs}$

3. $\mathrm{L}+\mathrm{SnAs} \leftrightarrow \mathrm{Sn}_{4} \mathrm{As}_{3}+\mathrm{GeAs}$

4. $\mathrm{L}+\mathrm{GeAs} \leftrightarrow \mathrm{Ge}+\mathrm{Sn}_{4} \mathrm{As}_{3}$

Given that the eutectic points on the tin side are degenerate in the $\mathrm{Ge}-\mathrm{Sn}$ and $\mathrm{Sn}-\mathrm{As}$ systems, we can expect that the coordinate of the four-phase equilibrium point $E_{1}$ will be implemented in the tin-rich area of the alloys. Eutectic crystallization of three solid phases $\mathrm{L} \leftrightarrow \mathrm{Ge}+\mathrm{Sn}+$ $\mathrm{Sn}_{4} \mathrm{As}_{3}$ takes place at the $\mathrm{E}_{1}$ point (Fig. 13).

The analysis of the nature of phase equilibria in the ternary $\mathrm{Sn}-\mathrm{As}-\mathrm{Ge}$ system, as well as the experimental study of polythermal sections $\mathrm{Sn}-\mathrm{GeAs}, \mathrm{Sn}_{4} \mathrm{As}_{3}-\mathrm{GeAs}$,
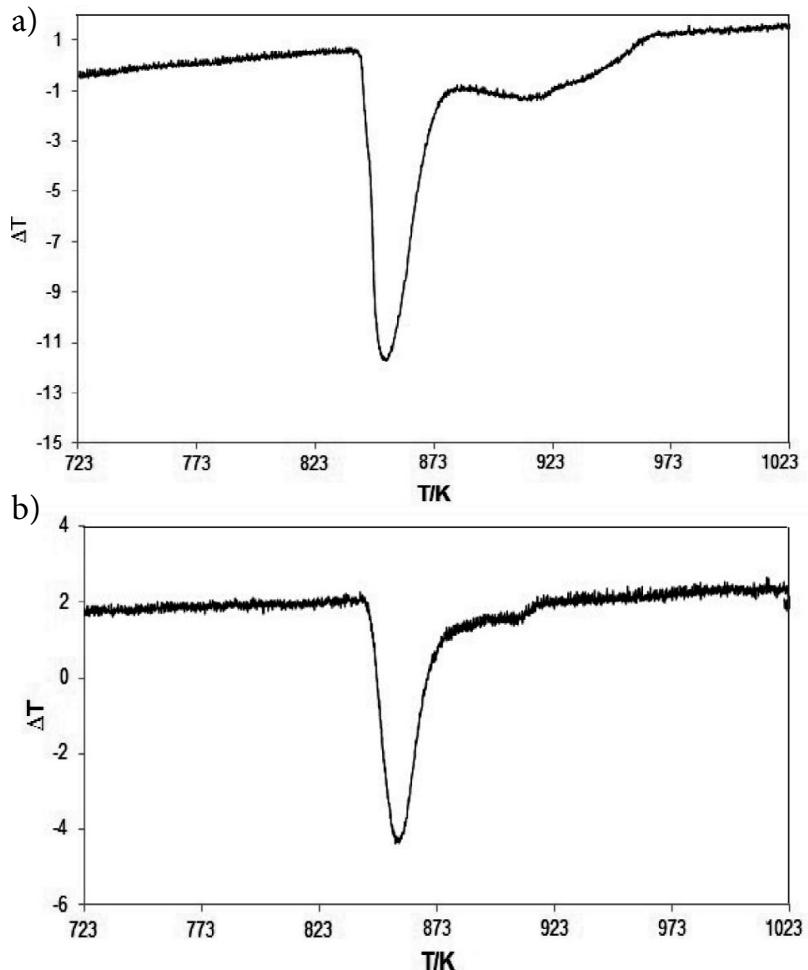

Figure 12. The DTA results in $\Delta \mathrm{T}-\mathrm{T}$ coordinates for $(\mathrm{SnAs})_{0.5}$ $\left(\mathrm{GeAs}_{2}\right)_{0.5}$ (a) and $\left(\mathrm{Sn}_{0.39} \mathrm{As}_{0.61}\right)_{0.7}\left(\mathrm{Ge}_{0.28} \mathrm{As}_{0.72}\right)_{0.3}$ (b) alloys.

$\mathrm{Sn}_{0.39} \mathrm{As}_{0.61}-\mathrm{Ge}_{0.28} \mathrm{As}_{0.72}$, SnAs-Ge $\mathrm{Ge}_{0.4} \mathrm{As}_{0.6}$, SnAs-GeAs and $\mathrm{SnAs}-\mathrm{GeAs}_{2}$ using the methods of differential thermal and X-ray diffraction analysis, allowed us to construct a $T-x-y$ diagram of the Sn-As-Ge system (Fig. 13).

It seemed impractical to use a $3 \mathrm{D}$ chart, whereas Sheila's scheme turned out to be quite informative and, most importantly, convenient for the analysis of the phase states and the processes of melting and crystallization, as well as for calculations and cross-sections building (Fig. 14).

The main objective was to reduce the three-dimensional diagram of the triple system to a one-dimensional scheme, which would give a clear idea of the phase equilibria in the system. We performed this reduction by taking into account nonvariant and monovariant transformations only, leaving out the concentration of phases and using only the temperature axis. The scheme shown in Fig.14 illustrates phase equilibria and successive (with decreasing temperature) crystallization processes in the ternary $\mathrm{Sn}-$ As-Ge system.

\section{Conclusions}

The polythermal sections of the phase diagram of the Sn-As-Ge ternary system were studied by differential thermal and X-ray analysis methods, which made it possible to represent the nature of phase equilibrium $\mathrm{L}+\mathrm{GeAs}$ $\leftrightarrow \mathrm{Ge}+\mathrm{Sn}_{4} \mathrm{As}_{3}(\mathrm{~T}=821 \mathrm{~K})$ in the system established ear- 


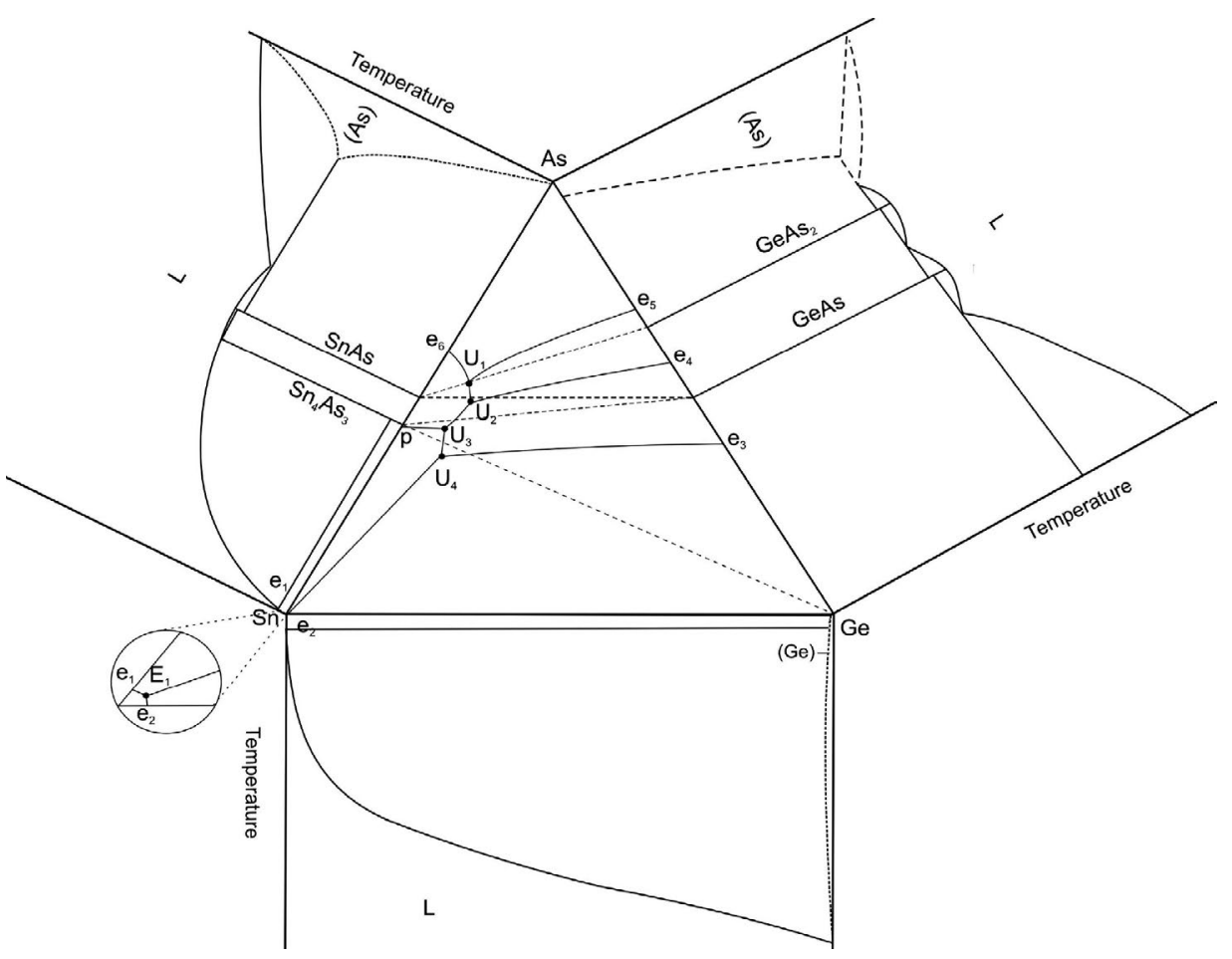

Figure 13. Sn-As-Ge phase diagram.

\section{Ge-As}

Ge-As-Sn

As-Sn

$1027 \mathrm{~L} \leftrightarrow \mathrm{Ge}+\mathrm{GeAs}^{\mathrm{e}_{3}}$
$1023 \mathrm{~L} \leftrightarrow \mathrm{GeAs}+\mathrm{GeAs}$
$1022 \mathrm{~L} \leftrightarrow \mathrm{CeAs}_{2}+\mathrm{As}$

$838 \mathrm{~L}+\mathrm{GeAs}_{2} \leftrightarrow \mathrm{GeAs}+\mathrm{SnAs} \mathrm{U}_{2}$

$\mathrm{GeAs}_{2}+\mathrm{GeAs}^{-\mathrm{SuAs}}$

$834 \mathrm{~L}+\mathrm{SnAs} \leftrightarrow \mathrm{GeAs}+\mathrm{Sn}_{4} \mathrm{As}_{3} \mathrm{U}_{3}$

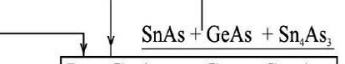

$821 \mathrm{~L}+\mathrm{GeAs} \leftrightarrow \mathrm{Ge}+\mathrm{Sn}_{4} \mathrm{As}_{3} \mathrm{U}_{4}$

$\underline{\mathrm{GeAs}+\mathrm{Ge}+\mathrm{Sn}_{4} \mathrm{As}_{3}}$

505

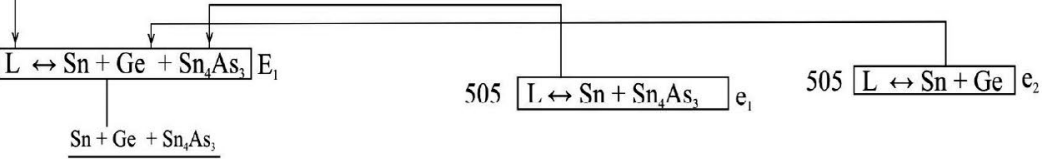

Figure 14. Flow diagram of the Sn-As-Ge system. 
lier during the study of the Ge-SnAs and $\mathrm{Sn}_{4} \mathrm{As}_{3}-\mathrm{GeAs}$ sections. It is also shown that, at a temperature close to the melting point of tin, an invariant equilibrium is realized involving a melt and three solid phases: tin, germanium monoarsenide and $\mathrm{Sn}_{4} \mathrm{As}_{3}$. This fact is not surprising, since in the binary systems $\mathrm{Ge}-\mathrm{Sn}$ and $\mathrm{Sn}$-As the eutectic points are degenerate. Investigation of alloys in the concentration region with an arsenic content of more than 50 mol. \% allowed to establish the presence of two more invariant processes. For samples whose compositions correspond to the concentration triangle formed by the figurative points GeAs, $\mathrm{GeAs}_{2}$ and $\mathrm{SnAs}$, the temperature of the first endoeffect equal to $840 \mathrm{~K}$ was recorded by differential thermal analysis. This value coincides with the temperature of the first effect for alloys of the GeAs-SnAs cross section. This can be explained by the existence at a given temperature of the peritectic invariant equilibrium $\mathrm{L}+$ $\mathrm{GeAs}_{2} \leftrightarrow \mathrm{GeAs}+\mathrm{SnAs}$, since the triple eutectic with these phases should have a lower temperature than for the GeAs-SnAs section. Investigation of the $\mathrm{SnAs}-\mathrm{GeAs}_{2}$ cross section and comparison of the results obtained with DTA data for samples with a high arsenic content made it possible to conclude that the equilibrium $\mathrm{L}+\mathrm{As} \leftrightarrow \mathrm{SnAs}$ $+\mathrm{GeAs}_{2}$ takes place at $843 \mathrm{~K}$. Thus, in the $\mathrm{Sn}-\mathrm{As}-\mathrm{Ge}$ ternary system there are five invariant equilibria, which are presented in the paper as a flow diagram.

\section{Acknowledgment}

The authors are grateful for the conduct of X-ray studies Center for collective use of scientific equipment of Voronezh State University.

\section{References}

1. C. Barreteau, B. Michon, C. Besnard, E. Giannini, J. Cryst. Growth. 2016, 443,75-80. DOI:10.1016/j.jcrysgro.2016.03.019

2. F. Shojaei, HS Kang, J. Phys. Chem. C. 2016, 120, 2384223850. DOI:10.1021/acs.jpcc.6b07903

3. K. Lee, S. Kamali, T. Ericsson, M. Bellard, K. Kovnir, Chem. Mater. 2016, 28(8), 2776-2785.

DOI:10.1021/acs.chemmater.6b00567

4. M. Khatun, A. Mar, Z. Naturforsch. 2016, 71(5), 375-380. DOI:10.1515/znb-2015-0203

5. K. Lee, S. Synnestvedt, M. Bellard, K. Kovnir, J. Solid State Chem. 2015, 224, 62-70. DOI:10.1016/j.jssc.2014.04.021

6. G. Klancnik , J. Medved, A. Nagode, G. Novak, D. Steiner Petrovic, J. Therm. Anal. Calorim. 2014, 116, 295-302. DOI:10.1007/s10973-013-3536-y

7. E. Kononova, S. Sinyova, G. Semenova, T. Sushkova, J. Therm. Anal. Calorim. 2014, 117(3), 1171-1177.

DOI:10.1007/s10973-014-3883-3

8. G. V. Semenova, E. Yu. Kononova, T.P. Sushkova, Russian J. Inorgan. Chem. 2014, 59(12), 1517-1521.

DOI: $10.1134 /$ S0036023614120225

\section{Povzetek}

V prispevku predstavljamo fazni diagram sistema Sn-As-Ge. Diagram v sistemu Sn-GeAs smo izdelali z uporabo rezultatov rentgenske praškovne difrakcijske analize in diferencialne termične analize. Ugotovili smo, da so v koncentracijskem intervalu z vsebnostjo arzena manj kot 50 mol\% prisotne štiri fazne v peritektičnem ravnotežju $\mathrm{L}+\mathrm{SnAs} \leftrightarrow \mathrm{GeAs}$ $+\mathrm{Sn}_{4} \mathrm{As}_{3}(834 \mathrm{~K})$ in $\mathrm{L}+\mathrm{GeAs} \leftrightarrow \mathrm{Ge}+\mathrm{Sn}_{4} \mathrm{As}_{3}(821 \mathrm{~K})$. Ko je temperatura blizu tališča čistega kositra, pride do invariantnega ravnotežja s kositrom, germanijem in $\mathrm{Sn}_{4} \mathrm{As}_{3}$. Podrobneje smo raziskali tudi sekcije $\mathrm{Sn}_{0.39} \mathrm{As}_{0.61}-\mathrm{Ge}_{0.28} \mathrm{As}_{0.72}, \mathrm{SnAs}$ $\mathrm{Ge}_{0.4} \mathrm{As}_{0.6}$ in SnAs-GeAs 2 in preučevali fazna diagrama SnAs-GeAs in SnAs-GeAs 2 v sistemu Sn-As-Ge. V sistemu smo tudi opazili invariantna peritektična ravnotežja $\mathrm{L}+\mathrm{GeAs}_{2} \leftrightarrow \mathrm{GeAs}+\mathrm{SnAs}(840 \mathrm{~K})$ in $\mathrm{L}+\mathrm{As} \leftrightarrow \mathrm{SnAs}+\mathrm{GeAs}_{2}(843 \mathrm{~K})$. 